\section{Water Use and Physiological Response of Tall Fescue Turf to Water Deficit Irrigation in an Arid Environment}

\author{
C.A. Brown ${ }^{1}$ \\ Department of Water Resource Management, University of Nevada Las Vegas, \\ Las Vegas, NV 89154
}

D.A. Devitt ${ }^{2}$

Department of Env. and Resource Sci. and Cooperative Extension, University of Nevada Reno, Las Vegas, NV 89154

\author{
R.L. Morris ${ }^{3}$ \\ Cooperative Extension, University of Nevada Reno, Las Vegas, NV 89154
}

Additional index words. water conservation, leaching fractions, irrigation frequencies, evapotranspiration, and nitrogen

\begin{abstract}
Research was conducted to assess the response of tall fescue (Festuca arundinacea Schreb.) to water deficit conditions. Different leaching fractions ( $\mathrm{LF}=$ drainage volume/irrigation volume) and irrigation frequencies (IF) were imposed over a 119-day summer period in Las Vegas, Nevada, followed by a 71-day recovery period. Plots of tall fescue contained $120 \mathrm{~cm}$ deep $\times 51 \mathrm{~cm}$ diameter draining lysimeters. Irrigations were based on an evapotranspiration (ET) feedback system to establish LFs of $+0.15,0.00$, $\mathbf{- 0 . 1 5}, \mathbf{- 0 . 2 5}$, and $\mathbf{- 0 . 4 0}$. Plots were irrigated on a daily or twice per week schedule. $\mathrm{N}$ was applied to subplots at a rate of $0,12.2$, or $24.4 \mathrm{~kg} \cdot \mathrm{ha}^{-1}$ per month. As LF decreased, relative soil water in storage declined in a linear fashion $\left(r^{2}=0.97, P=0.001\right)$. Storage depletions for the four lowest LFs at the end of 119 days of imposed water deficits were about $15 \%, 40 \%, 60 \%$, and $70 \%$ compared to the +0.15 LF treatment. Canopy temperature, soil matric potential $\left(\Psi_{\mathrm{m}}\right)$, leaf xylem water potential $\left(\Psi_{\mathrm{LX}}\right)$, leaf stomatal conductance $(\mathrm{g})$, clipping yield, color and cover ratings all statistically separated $(P<0.05)$ based on LF but not on IF. However, irrigation amount (I), ET, tissue moisture content and total Kjeldahl N (TKN) separated based on LF and IF with a significant LF by IF interaction for I $(P<0.05)$ and TKN $(P<0.001)$. An irrigation savings of $60.4 \mathrm{~cm}$ was realized during the 119-day water deficit period at the $-\mathbf{0 . 4 0} \mathrm{LF}$. However, at the lower LFs, plant stress increased (all parameters) with color ratings declining below an acceptable value of 8.0 . An Irrigation/Potential ET (I/ETo) threshold of 0.80 was determined for both color and cover. After a 71-day recovery period both color and cover returned to pre experimental values at the two higher $\mathbf{N}$ rates. Results of this experiment indicate that implementing a twice weekly irrigation strategy at a $\mathbf{- 0 . 1 5} \mathbf{~ L F}$ on tall fescue during summer months in an arid environment would lead to savings of $37.5 \mathrm{~cm}$ of water while still maintaining acceptable color and cover ratings.
\end{abstract}

Tall fescue dominates urban landscapes in southern Nevada because of its year round color and low maintenance. However, it has been clearly demonstrated to be a high water user, with crop coefficients $>1.0$ during summer months (Devitt et al. 1995). Southern Nevada is approaching its Colorado River allocation limit. Water managers are looking to conservation in the urban landscape to provide significant water savings. As southern Nevada continues to grow in population (currently $\approx 1.5$ million, 2002 Clark County Census) this

Received for publication 3 Dec. 2002. Accepted for publication 27 Apr. 2003. This paper is a portion of a thesis submitted by C.A.B. We wish to thank the U.S. Dept. of Agriculture and the College of Agriculture, Univ. of Nevada-Reno for financial support of this project. We also thank Jeff Andersen for assistance in the field and Linda Verchick for assistance in the laboratory.

${ }^{1}$ Graduate Student.

${ }^{2}$ Professor, Soil and Water.

${ }^{3}$ Associate Professor. will test the ability of the existing distribution system to meet peak water demands. Water management strategies must be developed not only for long-term savings but also for shortterm savings to help alleviate peak demand problems.

Turfgrass cultural management in southern Nevada currently emphasizes daily watering during the hot summer months to minimize turfgrass water stress [potential evapotranspiration $\left(\mathrm{ET}_{\mathrm{o}}\right)>1.0 \mathrm{~cm}$ per day]. Decreasing the frequency and imposing temporary water deficit conditions during peak summer months could provide significant water savings and a reduced demand on the distribution system. However, acceptance of such a strategy by turfgrass managers will be closely linked with the assurance that the turfgrass will be able to tolerate such stress, have an acceptable quality and make a full recovery once nondeficit irrigations are resumed during the nonpeak demand months.

Although tall fescue is a cool season grass, it has been demonstrated to tolerate a wide range in soil and climatic conditions (Beard, 1973; Carrow, 1996; Ervin and Koski, 1998; Kim and Beard, 1988; Turgeon and Giles, 1987). Qian et al. (1997) found that tall fescue had greater total root length and maximum root extension than warm season grasses providing greater leaf wilt resistance during drought. Fry and Butler (1989) found that drought resistance of tall fescue prevented large decreases in turf appearance as soils dried and observed little correlation between soil matric potential $\left(\Psi_{\mathrm{m}}\right)$ and turf quality scores. White et al. (1992) found that tall fescue was able to maintain positive leaf turgor, when exposed to drought conditions in a laboratory experiment. However, once a soil moisture threshold was exceeded, leaf water potential declined rapidly and leaf rolling increased dramatically.

Nitrogen management is a tool in water conservation that is often overlooked. Increased $\mathrm{N}$ applications typically lead to increased shoot growth, which leads to increased water use. Campbell (1977) demonstrated that high rates of $\mathrm{N}$ applied to spring wheat grown under semi-arid conditions induced rapid growth of leaves and roots, accelerating the rate of evapotranspiration (ET) and the depletion of limited soil moisture.

The objective of this study was to investigate the water use and physiological response of tall fescue placed under various combinations of irrigation frequency (IF) and leaching fractions (LF) during summer months in an arid environment. Additional objectives were to determine the degree of recovery of the grass when water deficit conditions were lifted and to determine the role of $\mathrm{N}$ on the stress and recovery responses of the turf.

\section{Material and Methods}

A field experiment was initiated at the Center for Urban Water Conservation in North Las Vegas, Nev., on 21 May 1997 (Day 1), to determine potential water savings and plant response of 'Monarch' tall fescue to various combinations of IF and LF. Tall fescue (3-yearold stands, originally sodded) was grown in 20 experimental plots $(5.5 \mathrm{~m} \times 5.5 \mathrm{~m})$, separated by $\approx 6.7-\mathrm{m}$ buffer areas seeded to 'Monarch' tall fescue. The experimental design included treatments of five leaching fractions; each with two irrigation frequencies randomized and replicated in the same field $(n=20)$, with three subplot nitrogen treatments $(n=60$, not fully randomized). Each of the plots had a $120-\mathrm{cm}$ deep, 51-cm diameter draining lysimeter in the center, which was used to calculate ET of the turfgrass. The lysimeters were each filled with blended native surface soil from the same field to reduce variations between lysimeters. The lysimeters were drained by means of two ceramic drainage extraction cups placed in a 10 -cm layer of diatomaceous earth at the bottom of each lysimeter. In the center of each lysimeter was an access tube that allowed the lowering of a neutron probe (Troxler Electronics Laboratory, Research Triangle Park, N.C.) for indirect measurements of soil volumetric water contents at depths of $20,40,60$, and 
$80 \mathrm{~cm}$. Total soil water in storage was estimated by integrating the water contents over the entire soil depth.

Irrigation cells (four sprinklers delivering water to a single plot) were designed such that the distance between plots minimized water application, runoff, or both, from one plot to another. Each plot contained four popup sprinklers (Toro 300 series, Toro Corp., St. Paul, Minn., 276 kilonewtons $/ \mathrm{m}^{2}$ ) equally spaced $(5.5 \mathrm{~m})$. Each irrigation plot had a single pressure regulator with a mounted Shrader valve for monitoring pressure. Irrigation volumes applied to the lysimeters were estimated by measuring the volume of water that was collected in catch-cans (situated on each lysimeter) during irrigation events. Uniformity distributions were evaluated on each plot prior to the experiment (Hart and Reynolds, 1965; uniformity coefficient of greater than 0.82). Soil at the site was classified as a Las Vegas Loam (loamy, carbonitic, thermic shallow typic petrocalcid).

Actual ET (ET $)_{\mathrm{a}}$ was estimated by constructing a hydrologic balance for each lysimeter on a weekly basis by using the equation, ET = Irrigation (I) + Precipitation (P) - Drainage (D) - Change in Storage (S). ET feedback was then used to schedule irrigations. Irrigations applied to the lysimeter were based on imposing leaching fractions of 0.15 , $0.00,-0.15,-0.25$, or -0.40 (where negative LFs are theoretical), based on the equation $\mathrm{I}=\mathrm{ET} /(1-\mathrm{LF})$. The frequency of irrigation was set at either a daily or twice per week rate. Each treatment combination of LF and irrigation frequency was replicated twice in a randomized block design. All irrigations were applied between 0600 and $1200 \mathrm{HR}$, with enough time between multiple applications to avoid runoff and puddling.

Meteorological conditions were monitored with an automated weather station (Campbell Scientific, Logan, Utah). Hourly measurements of solar radiation, maximum and minimum temperature, relative humidity $(\mathrm{RH})$, wind speed and rainfall were downloaded to a computer. Potential evapotranspiration $\left(\mathrm{ET}_{\mathrm{o}}\right)$ was estimated with a modified Penman-Montieth equation (Campbell Scientific), with cut grass at a height of $5.1 \mathrm{~cm}$.

In addition to irrigation treatments, each plot was subdivided into three $1.8-\mathrm{m}$ wide subplots, given monthly ammonium nitrate (N) applications $(21 \mathrm{~N}-0 \mathrm{P}-0 \mathrm{~K})$ at rates of 0 , 12.2 , or $24.4 \mathrm{~kg} \cdot \mathrm{ha}^{-1}$ per month. The center subplots containing the lysimeters all received the $\mathrm{N}$ at the rate of $24.4 \mathrm{~kg} \cdot \mathrm{ha}^{-1}$ per month, however, the other two $\mathrm{N}$ treatments were randomized. Phosphorus was applied prior to the experiment as triple superphosphate at the rate of $38.8 \mathrm{~kg} \cdot \mathrm{ha}^{-1}\left(\mathrm{P}_{2} \mathrm{O}_{5}\right)$. Based on tissue analysis, potassium was deemed adequate $\left(>20 \mathrm{~g} \cdot \mathrm{kg}^{-1}\right)$ and no application was made. No pesticides were applied during the course of the experiment.

The effects of LF, IF, and $\mathrm{N}$ treatments on the soil-plant water status of tall fescue were monitored. Tensiometers were placed in each lysimeter at a $30-\mathrm{cm}$ depth to measure $\Psi_{\mathrm{m}}$. Leaf xylem water potential $\left(\Psi_{\mathrm{LX}}\right)$ was mea- sured by means of a plant water status console (pressure bomb, Soil Moisture Corp., Santa Barbara, Calif.) at mid-day. Leaf stomatal conductance $\left(\mathrm{g}_{\mathrm{s}}\right)$ was measured with a steadystate porometer (LI-COR, Lincoln, Nebr.). Canopy temperature $\left(T_{c}\right)$ was measured with an infrared thermometer (Everest Interscience, Tustin, Calif.). All of these measurements were taken at solar noon on a biweekly basis until a plant stress response was apparent; thereafter the measurements were increased to a weekly basis until the end of the stress period. At that point in time, a recovery irrigation treatment (+0.15 LF, daily irrigation) was imposed on all plots.

Clipping weight was measured weekly on both subplots and lysimeters. Turfgrass was harvested from each subplot by mowing a single strip $\left(2.9 \mathrm{~m}^{2}\right)$ through the center of each subplot at a $5.1-\mathrm{cm}$ height. The turfgrass was collected in plastic bags, sealed, placed in a cooler and delivered to the laboratory where it was weighed to determine total fresh weight. The sample was then oven dried for $48 \mathrm{~h}$ at $70{ }^{\circ} \mathrm{C}$ to determine tissue moisture content (grams of $\mathrm{H}_{2} \mathrm{O} / \mathrm{g}$ fresh weight) and dry yield of each sample.

Turf color and cover were visually evaluated by two evaluators at the same time plant physiological measurements were taken. Measurements were made at three evenly spaced sites within each subplot. Turf color was reported on a scale of $1-10$ with 1 as brown dead grass, 10 as dark green healthy turf and 8 as a minimally acceptable color rating. Turf cover was reported on a scale of $0-100$, representing the percentage of area covered by green turfgrass.

Tissue $\mathrm{N}$ content was evaluated as total Kjeldahl nitrogen (TKN) of samples taken on Day 100 (peak environmental demand) at three evenly spaced sites within each subplot. After oven drying $\left(70{ }^{\circ} \mathrm{C}\right)$, three 0.05 -g samples of turfgrass harvested from each subplot were digested in sulfuric acid with a mercuric oxide catalyst using a block digester. The samples were then analyzed colorimetrically for TKN using an automated salicylate procedure (Perstop Analytical, 1994).

Statistical analysis was run on data sets collected from the lysimeters and the subplots. A multivariate analysis of the data (MANOVA) was run based on LF, IF and when applicable, the $\mathrm{N}$ application rate. The data were analyzed on Day 100, on the final day of the stress period (Day 119) and at the end of the recovery period (Day 189). The data were also analyzed using multiple regression analysis. Multiple regressions were performed in a backward stepwise manner, with deletion of terms occurring when $P$ values for the $t$ test exceeded 0.05 . Average treatment values were compared based on a least significance difference (LSD) generated from a mean square of the error term from the corresponding analysis of variance (ANOVA).

\section{Results}

Soil water status. The experiment was designed to establish clear differences in soil water status by varying both LF and IFs. All plots irrigated at or below the $0.00 \mathrm{LF}$ depleted soil water in storage relative to the maximum storage $\left(\right.$ Storage $\left._{\max }\right)$ of the +0.15 LF measured on the first day of the experiment (Julian Day 141). The ratio of water in storage at the end of the stress period, relative to the maximum storage value was highly correlated to the LF $\left(\mathrm{S} / \mathrm{S}_{\max }=0.7822+1.2634 \mathrm{LF}, R^{2}=0.97 * * *\right)$. Storage depletions were $\approx 15 \%, 40 \%, 60 \%$, and $70 \%(0.00,-0.15,-0.25$, and -0.40$)$ of the maximum storage after $119 \mathrm{~d}$ of imposed treatments. Data from all treatments were included in this linear regression, regardless of the IF, which had a nonsignificant impact on the relationship (Table $1, P=0.904, \mathrm{n}=$ 20). In this experiment, a highly significant correlation existed between the irrigation volume divided by $\mathrm{ET}_{\mathrm{o}}\left(\mathrm{I} / \mathrm{ET}_{\mathrm{o}}\right)$ and the $\mathrm{LF}\left(\mathrm{I} / \mathrm{ET}_{\mathrm{o}}\right.$ $\left.=1.04+1.03 \mathrm{LF}, R^{2}=0.96 * * *\right)$, suggesting that irrigators could use such a relationship to predict LFs in the field (for a similar soil, grass and nitrogen level). An I/ET of 1.0 correlated with a LF of -0.04 , indicating that tall fescue water requirements are greater than $\mathrm{ET}_{\mathrm{o}}$ during summer months in southern Nevada.

The $\Psi_{\mathrm{m}}$ was measured in each lysimeter at a depth of $30 \mathrm{~cm}$. Estimates of $\Psi_{\mathrm{m}}$ showed separation by LF (Table $1, P=0.001, \mathrm{n}=$ 16), but not separation by IF $(P=0.758, \mathrm{n}=$ 16). On the final day of the stress period (Day 119), $\Psi_{\mathrm{m}}$ decreased in a linear fashion with the LF $(-0.40 \mathrm{LF}$ not included due to loss in suction, $\Psi_{\mathrm{m}}(\mathrm{KPa})=-26.31+174.52 \mathrm{LF}, R^{2}$ $=0.83 * * *$ ).

Water balance and ET estimates. The water balance for each treatment is reported in Table 2. The ANOVA indicated that irrigation amounts applied based on the ET feedback approach separated based upon the LF imposed (Table $1, P=0.001, \mathrm{n}=20)$, the $\operatorname{IF}(P=0.01$, $\mathrm{n}=20)$ and a LF by IF interaction $(P=0.05$, $\mathrm{n}=20$ ). A decrease in irrigation or savings of $60.4 \mathrm{~cm}$, equivalent to a $47 \%$ reduction, occurred over the 119-d stress period when the $-0.40 \mathrm{LF}$ was compared to the +0.15 LF. Even a savings of $19.8 \mathrm{~cm}$ over this same time period occurred when the +0.15 LF was compared to the $0.00 \mathrm{LF}$ treatment.

Plots receiving less water due to lower LFs, resulted in greater depletion of soil water in storage and in lower ET values. Statistical separation of ET occurred based on LFs $(P=0.01, \mathrm{n}=20)$ and IF $(P=0.05, \mathrm{n}=20)$. When ET was plotted against LF (Fig. 1) for each IF treatment, statistical separation occurred at all LFs except -0.40 . The slope of the daily irrigation treatment (from LF -0.40 to LF 0.00 ) was higher than that of the twice-weekly treatment, with a drop in value at +0.15 LF. Actual evapotranspiration $\left(\mathrm{ET}_{\mathrm{a}}\right)$ data from the twice-weekly irrigation treatment had a positive linear correlation with LF (ET $\left.=95.9+28.9 \mathrm{LF}, R^{2}=0.68^{* *}\right)$. However, in the daily irrigation treatment a second order polynomial $\left(\mathrm{ET}=103.1-26.8 \mathrm{LF}-2.22 \mathrm{LF}^{2}\right.$, $\left.R^{2}=0.93 * * *\right)$ was required to account for the significant decline in ET at the highest LF. The $\mathrm{ET}_{\mathrm{a}}$ showed clear separation from $\mathrm{ET}_{\mathrm{o}}$ in the $-0.40 \mathrm{LF}$ treatment by Day 59 (data not shown) and only returned to similar $\mathrm{ET}_{\mathrm{o}}$ values 
Table 1. Significant effects of LF, IF, and $\mathrm{N}$ on various soil and plant parameters based on multivariate analysis of the data (end of 119-d water deficit period).

\begin{tabular}{|c|c|c|c|c|c|c|c|c|c|c|c|c|c|c|}
\hline Factor & df & $g_{s}$ & $\Psi_{L X}$ & $\Psi_{\mathrm{M}}$ & $\begin{array}{c}\text { Storage/ } \\
\text { Storage }^{\text {Max }}\end{array}$ & $\mathrm{ET}_{\mathrm{a}}$ & I & Drainage & Color & Cover & $\begin{array}{l}\text { Tissue } \\
\text { moisture }\end{array}$ & $\mathrm{T}_{\mathrm{c}}-\mathrm{T}_{\mathrm{a}}$ & $\begin{array}{c}\text { Dry } \\
\text { yield }\end{array}$ & $\mathrm{TKN}^{\mathrm{z}}$ \\
\hline$\overline{\mathrm{LF}}$ & 4 & $* * *$ & $* * *$ & *** & $* * *$ & $* *$ & **** & *** & $* * *$ & **** & $* * *$ & $* * *$ & **** & $* * *$ \\
\hline IF & 1 & NS & NS & NS & NS & $*$ & NS & NS & NS & NS & * & NS & NS & NS \\
\hline $\mathrm{N}$ & 2 & $\mathrm{y}$ & y & y & $\mathrm{y}$ & y & $\mathrm{y}$ & $\mathrm{y}$ & $* * *$ & NS & \multirow{2}{*}{$\begin{array}{l}\text { NS } \\
* *\end{array}$} & NS & $* * *$ & \multirow{2}{*}{$\begin{array}{c}\text { NS } \\
* * *\end{array}$} \\
\hline $\mathrm{LF} \times \mathrm{IF}$ & 4 & NS & NS & NS & NS & NS & $*$ & NS & NS & NS & & NS & NS & \\
\hline $\mathrm{LF} \times \mathrm{N}$ & 8 & $\mathrm{y}$ & y & y & y & y & y & y & $\mathrm{y}$ & NS & NS & NS & NS & NS \\
\hline $\mathrm{IF} \times \mathrm{N}$ & 2 & $\mathrm{y}$ & y & y & y & $\mathrm{y}$ & y & y & y & NS & NS & NS & NS & NS \\
\hline $\mathrm{LF} \times \mathrm{IF} \times \mathrm{N}$ & 8 & y & y & $\mathrm{y}$ & y & y & y & y & NS & NS & NS & NS & NS & \\
\hline
\end{tabular}

${ }^{\mathrm{z}} 100 \mathrm{~d}$ of treatment.

${ }^{\mathrm{y}} \mathrm{N}$ level held constant on all lysimeters.

ns, *,**,**** Nonsignificant or significant at $P \leq 0.05,0.01$, or 0.001 , respectively.

once the deficit irrigation period ended (Day 119). In contrast, the ET values for the +0.15 LF treatment remained extremely close to the $\mathrm{ET}_{\mathrm{o}}$ values, even during the declining $\mathrm{ET}_{\mathrm{o}}$ fall/winter period (data not shown).

Plant response. Leaf xylem water potential $\left(\Psi_{\mathrm{LX}}\right)$ measured at mid-day over the water deficit period separated based on LF (Table 1 , $P=0.001, \mathrm{n}=20)$ but did not separate based on IF $(P=0.315, \mathrm{n}=20)$. The lowest $\Psi_{\mathrm{LX}}$ values were recorded in the $-0.40 \mathrm{LF}$ plots on day 253. Daily irrigated -0.40 plots fell to $-4.28 \pm 0.03 \mathrm{MPa}$, while the twice weekly irrigated plots fell to $-3.42 \pm 0.71 \mathrm{MPa}$. Average $\Psi_{\mathrm{LX}}$ values for the $-0.40,-0.25,-0.15,0.00$, and +0.15 LF treatments for the 119-d stress period were $-3.45 \pm 0.15,-1.95 \pm 0.41,-1.45$ $\pm 0.25,-1.26 \pm 0.15$, and $-1.11 \pm 0.15 \mathrm{MPa}$. On the final day of the stress period $\Psi_{\mathrm{LX}}$ was positively correlated with $\mathrm{LF}\left(\Psi_{\mathrm{LX}}=-1.33+\right.$

Table 2. Water balance parameters separated by leaching fraction

(LF) and irrigation frequency [daily (D) and twice weekly

(TW)] for the 119-d water deficit period.

\begin{tabular}{|c|c|c|c|c|c|c|c|}
\hline \multirow[b]{2}{*}{ LF } & \multicolumn{2}{|c|}{ Irrigation } & \multicolumn{2}{|c|}{ Drainage } & \multicolumn{2}{|c|}{$\mathrm{ET}_{\mathrm{a}}$} & \multirow[b]{2}{*}{$\mathrm{ET}_{\mathrm{o}}$} \\
\hline & $\mathrm{D}$ & TW & $\mathrm{D}$ & TW & $\overline{\mathrm{D}}$ & $\overline{\mathrm{TW}}$ & \\
\hline+0.15 & 127.6 & 127.2 & 31.3 & $\begin{array}{l}-\mathrm{cm} \\
29.1\end{array}$ & 93.8 & 99.1 & $105 . .4$ \\
\hline 0.00 & 112.9 & 102.2 & 5.6 & 11.4 & 105.0 & 96.6 & --- \\
\hline-0.15 & 95.3 & 90.1 & 0.7 & 1.9 & 102.1 & 93.4 & --- \\
\hline-0.25 & 85.9 & 76.7 & 3.1 & 1.3 & 96.1 & 88.2 & --- \\
\hline-0.40 & 66.5 & 67.5 & 0.1 & 0.1 & 82.2 & 83.5 & --- \\
\hline $\mathrm{LSD}_{0.05}$ & \multicolumn{2}{|c|}{2.7} & \multicolumn{2}{|c|}{3.4} & \multicolumn{2}{|c|}{3.4} & \\
\hline
\end{tabular}

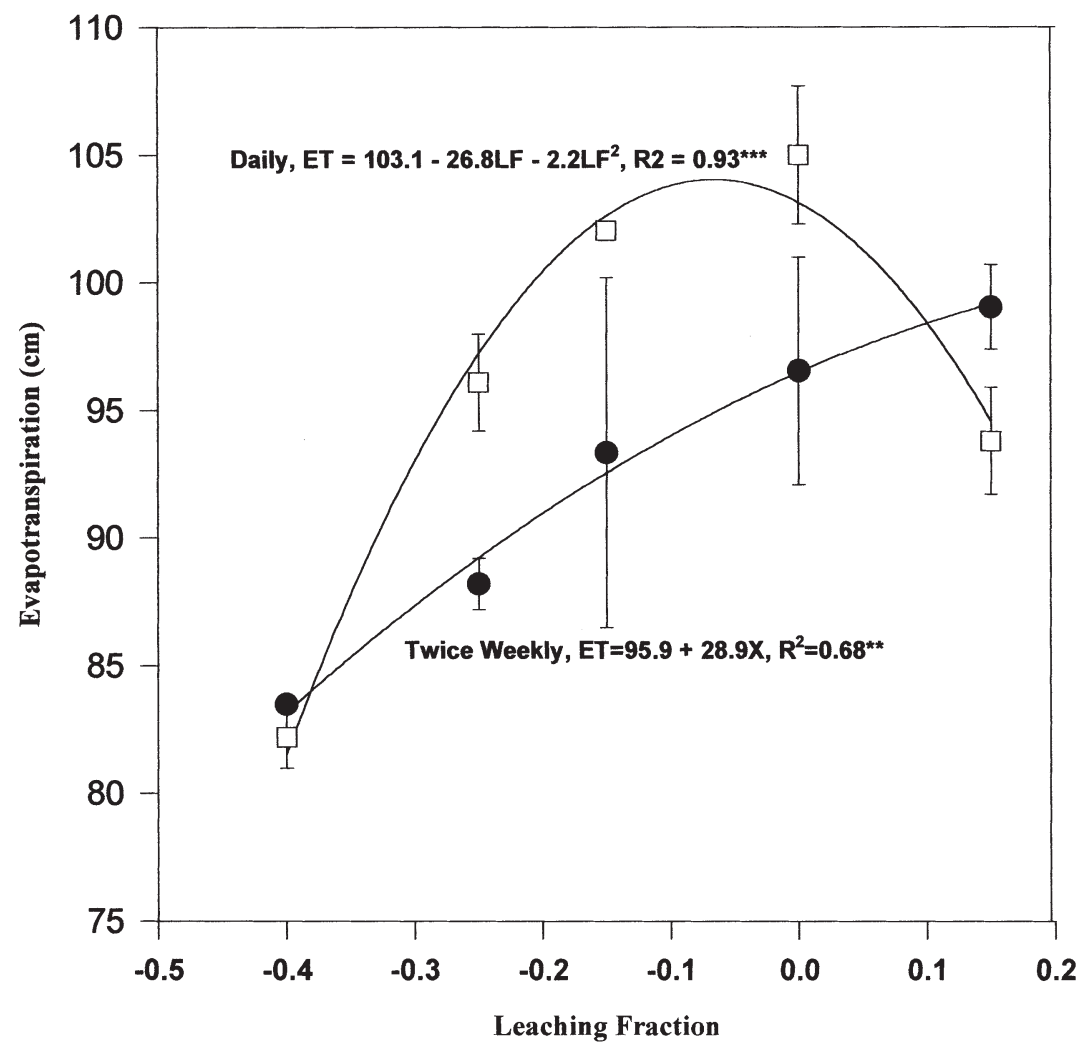

Fig. 1. Evapotranspiration of tall fescue as a function of leaching fraction and irrigation frequency for the 119-d water deficit period, where bars represent standard errors

\section{$\left.3.94 \mathrm{LF}, R^{2}=0.67 * * *\right)$.}

Stomatal conductance $\left(\mathrm{g}_{\mathrm{s}}\right)$ separated based on LF (Table $1, P=0.01, \mathrm{n}=20$ ) but did not separate based on $\operatorname{IF}(P=0.784, \mathrm{n}=20)$. Highest $g_{\mathrm{s}}$ values $\left(321.8 \pm 80.6 \mathrm{~mol} \cdot \mathrm{m}^{-2} \cdot \mathrm{s}^{-1}\right)$ for the stress period were measured in the $0.00 \mathrm{LF}$ (as was the highest ET values for the twice weekly treatment). Average $g_{\mathrm{s}}$ values for the other $\mathrm{LF}$ treatments $(+0.15,-0.15,-0.25$, and -0.40 LF) were $267.3 \pm 80.6,254.3 \pm 65.1,198.5$ \pm 35.8 and $93.5 \pm 76.8 \mathrm{~mol} \cdot \mathrm{m}^{-2} \cdot \mathrm{s}^{-1}$. Stomatal conductance correlated with $\Psi_{\mathrm{LX}}$ in a linear fashion at the end of the stress period $\left(\mathrm{g}_{\mathrm{s}}=\right.$ $\left.365.6+75.3 \Psi_{\mathrm{LX}}, R^{2}+0.55^{* * *}\right)$.

Turfgrass canopy temperature differentials (Tc-Ta, where $\mathrm{Ta}$ is ambient temperature) separated based on $\operatorname{LF}(P=0.001, \mathrm{n}=180)$ but not by IF or by $\mathrm{N}$ fertilization rate $(P=0.997$ and $P=0.803$ respectively, $\mathrm{n}=180)$. $\mathrm{T}_{\mathrm{c}}-\mathrm{T}_{\mathrm{a}}$ values increased as stress and water deficits increased. A $>7{ }^{\circ} \mathrm{C}$ temperature differential occurred between the +0.15 and $-0.40 \mathrm{LF}$ treatments on the last day of imposed water deficits. $T_{c}-T_{a}$ was inversely correlated with $\mathrm{LF}$ at the end of the stress period $\left(\mathrm{T}_{\mathrm{c}}-\mathrm{T}_{\mathrm{a}}=0.5\right.$ $-12.8 \mathrm{LF}, R^{2}=0.43^{*}$ ). Average $\mathrm{T}_{\mathrm{c}}-\mathrm{T}_{\mathrm{a}}$ for the stress period based on LFs was $-0.15+2.0$, $0.0 \pm 1.5,1.0 \pm 2.2,2.9 \pm 2.9$, and $7.2 \pm 3.2$ ${ }^{\circ} \mathrm{C}$ for the $+0.15,0.00,-0.15,-0.25$, and -0.40 LFs, respectively.

Tissue moisture content of turfgrass clippings measured on the last day of the water deficit period separated based on LF $(P=$ $0.001, \mathrm{n}=180)$, on $\operatorname{IF}(P=0.05, \mathrm{n}=180)$ and on a LF by IF interaction $(P=0.01, \mathrm{n}=$ 180). Average tissue moisture contents ranged from $48 \% \pm 15 \%$ for the $-0.40 \mathrm{LF}$ to $69 \% \pm$ $6 \%$ for the +0.15 LF. Tissue moisture content was linearly correlated with Tc-Ta on the last day of the stress period (Tissue Moisture (\%) $\left.=0.61-0.03 \mathrm{Tc}-\mathrm{Ta}, R^{2}=0.87 * * *\right)$.

Turfgrass clipping yield $(\mathrm{g})$ separated based on $\operatorname{LF}(P=0.001, \mathrm{n}=60)$ and $\mathrm{N}$ fertilization rate $(P=0.001, \mathrm{n}=60)$ but not on $\operatorname{IF}(P=$ $0.652, \mathrm{n}=60$ ). Yield as a function of LF and $\mathrm{N}$ fertilization is plotted in Fig. 2. Although yield and $\mathrm{N}$ were linearly correlated at all three $\mathrm{N}$ rates, $R^{2}$ values increased as $\mathrm{N}$ increased. A multiple regression analysis revealed that $\mathrm{N}$ and LF were positively correlated with yield (Yield $\left.(\mathrm{g})=143+259 \mathrm{LF}+3.6 \mathrm{~N}, R^{2}=0.60 * * *\right)$.

Turfgrass color ratings separated based on $\mathrm{LF}(P=0.001, \mathrm{n}=180)$ and $\mathrm{N}$ fertilization $(P=$ $0.001, \mathrm{n}=180)$, but not on IF. Color ratings for the twice-weekly irrigation frequency by $\mathrm{N}$ fertilization rates are plotted as a function of time in Fig. 3. Lowest color ratings during 


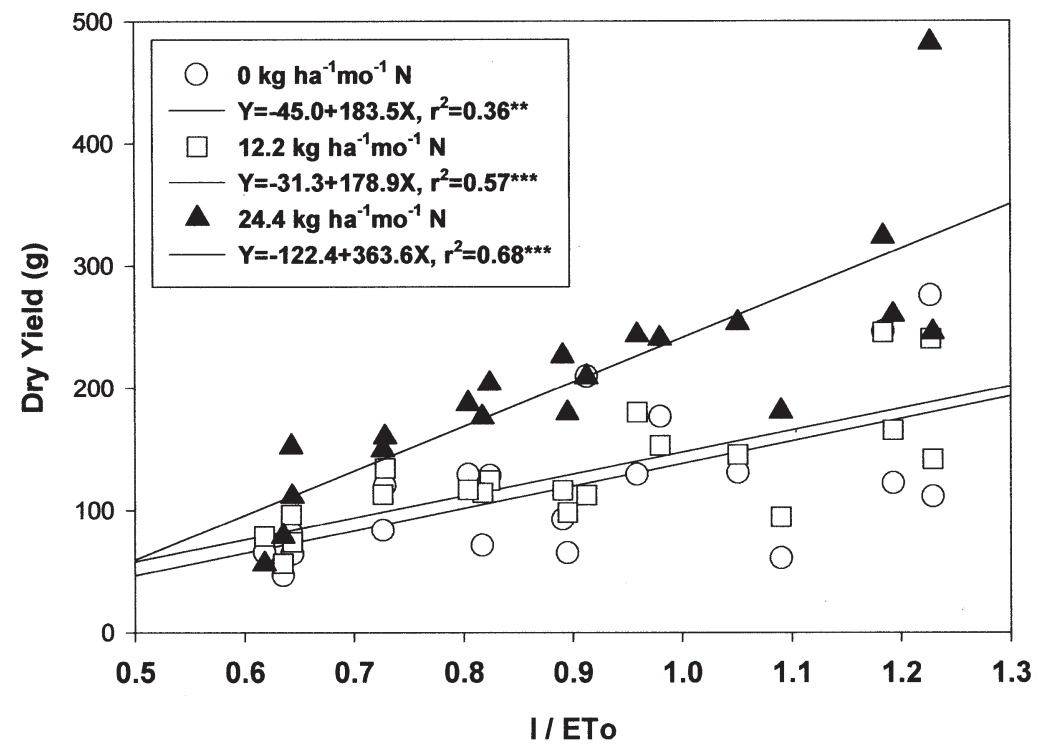

Fig. 2. Yield of tall fescue as a function of I/ETo and $\mathrm{N}$ application rates at the end of the 119-d water deficit period.

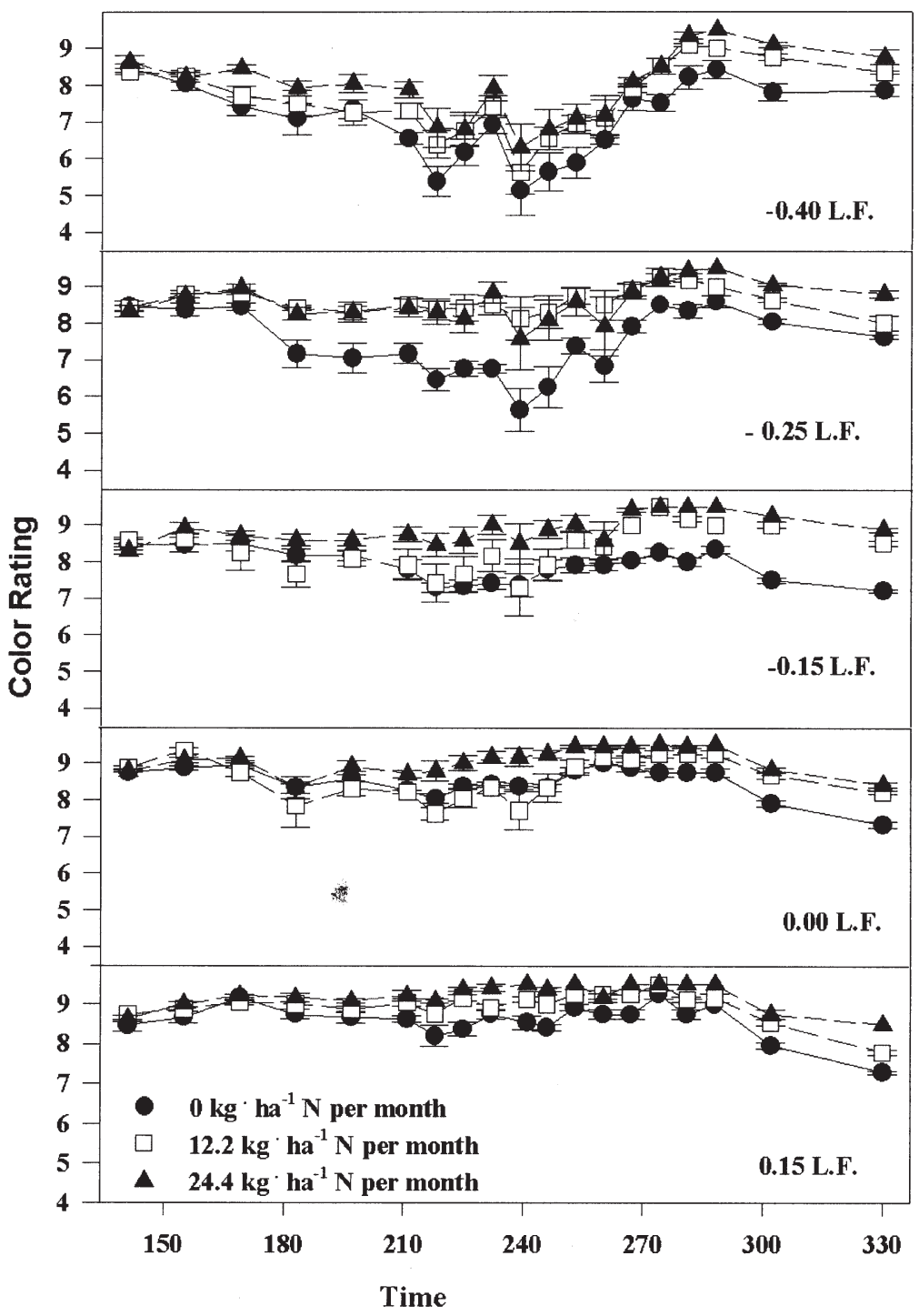

Fig. 3 Color rating of tall fescue irrigated twice weekly as a function of leaching fraction and $\mathrm{N}$ application rates, where bars represent standard errors. the stress period occurred in the $-0.40 \mathrm{LF}$ treatments on Day 253 (4.3 \pm 1.9 for daily, $\mathrm{N}$ at $12.2 \mathrm{~kg} \cdot \mathrm{ha}^{-1}$ per month vs. $5.1 \pm 1.7$ for daily, $\mathrm{N}$ at $0 \mathrm{~kg} \cdot \mathrm{ha}^{-1}$ per month). Highest color ratings occurred in the highest $\mathrm{N}$ fertilization treatments with a decline in color occurring by the end of the stress period in only the -0.25 and $-0.40 \mathrm{LF}$ treatments. Fifty-eight percent of the variation in color could be accounted for by incorporating $\Psi_{\mathrm{LX}}$ into a linear regression equation $\left(\right.$ Color $=10.12+0.81 \Psi_{\mathrm{LX}}, R^{2}=$ $0.58 * * *)$. Tradeoffs between water savings, plant stress and loss in turfgrass color were observed. Water savings of $\approx 30 \%(-0.25 \mathrm{LF}$ + high $\mathrm{N}$ lysimeters) could be obtained with an average color rating just above 8.0 and an average $\Psi_{\mathrm{LX}}$ measured above $-2.0 \mathrm{MPa}$. An $\mathrm{I} / \mathrm{ET}_{\mathrm{o}}$ threshold for color was determined on Day 119 to be $\approx 0.80$, as color decreased dramatically at lower I/ET values (Fig. 4).

Cover ratings separated based on LF ( $P=0.002, \mathrm{n}=180)$ but not by IF or $\mathrm{N}$ fertilization rate $(P=0.587$ and $P=0.295$ respectively, $\mathrm{n}=180$ ). At the end of the 119$\mathrm{d}$ stress period, the $+0.15 \mathrm{LF}$ treatment had a mean cover rating of $99.6 \% \pm 1.4 \%$. As irrigation deficit increased turfgrass cover declined. The -0.40 LF treatments declined to a mean value of $56.1 \% \pm 19.6 \%$, whereas the $-0.25 \mathrm{LF}$ treatment declined to $82.9 \%$ $\pm 2.5 \%$ (lowest measured values). Both the -0.15 and $0.0 \mathrm{LF}$ treatments remained at cover ratings above $90 \%$. Color and cover ratings at the end of the stress period were positively correlated in a linear fashion (Cover $=-26.1$ +13.4 (Color), $\left.R^{2}=0.57 * * *\right)$. Cover also had a well-defined I/ET o threshold on Day 119, declining dramatically after a value of 0.80 had been exceeded (Fig. 4).

Tissue nitrogen (TKN) concentrations measured on Day 100 separated by all three factors (LF, $P=0.001, \mathrm{~N}, P=0.001$ and IF, $P=0.05, \mathrm{n}=180)$. Mean values of TKN were $14 \pm 3 \mathrm{~g} \cdot \mathrm{kg}^{-1}$ for the $-0.40 \mathrm{LF}, 0 \mathrm{~N}$ treatment, whereas at $+0.15 \mathrm{LF}$ and $\mathrm{N}$ at $24.4 \mathrm{~kg} \cdot \mathrm{ha}^{-1}$ per month, the mean TKN concentration was $26 \pm$ $3 \mathrm{~g} \cdot \mathrm{kg}^{-1}$. A multiple linear regression analysis could account for $57 \%$ of the variability in the TKN concentration if LF, IF and $\mathrm{N}$ fertilization rate were included $(\mathrm{TKN}=17.6+0.24 \mathrm{~N}+$ $\left.11.5 \mathrm{LF}+0.02 \mathrm{IF}, R^{2}=0.57 * * *\right)$. Both tissue moisture and TKN showed a linear correlation with color ratings on Day $100($ Color $=2.90+$ 9.25 (Tiss. Moist.), $R^{2}=0.75^{* * *}$, Color $=3.19$ $\left.+0.23 \mathrm{TKN}, R^{2}=0.36^{* * *}\right)$. However, when an interactive term, defined as TKN $\times$ tissue moisture content was plotted against color and fit to a second order polynomial equation, a significantly higher amount of the color rating could be accounted for $($ Color $=2.75+0.68 \mathrm{X}$ $-0.02 \mathrm{X}^{2}, R^{2}=0.96 * * *$, where $\mathrm{X}=\mathrm{TKN} \times$ tissue moisture). Mean color ratings for the -0.25 and $-0.15 \mathrm{LF}$ treatments at $24.4 \mathrm{~kg} \cdot \mathrm{ha}^{-1}$ of $\mathrm{N}$ per month were $\geq 8.0$, but fell below this value at lower $\mathrm{N}$ fertilization rates.

Recovery. After the treatment period ended (Day 119), a recovery period was imposed in which all plots were irrigated at $0.15 \mathrm{LF}$. By Day 137, all treatment plots recovered to equal or better than pre-experimental color and cover ratings ( $100 \%$ cover, $>8.0$ color), 


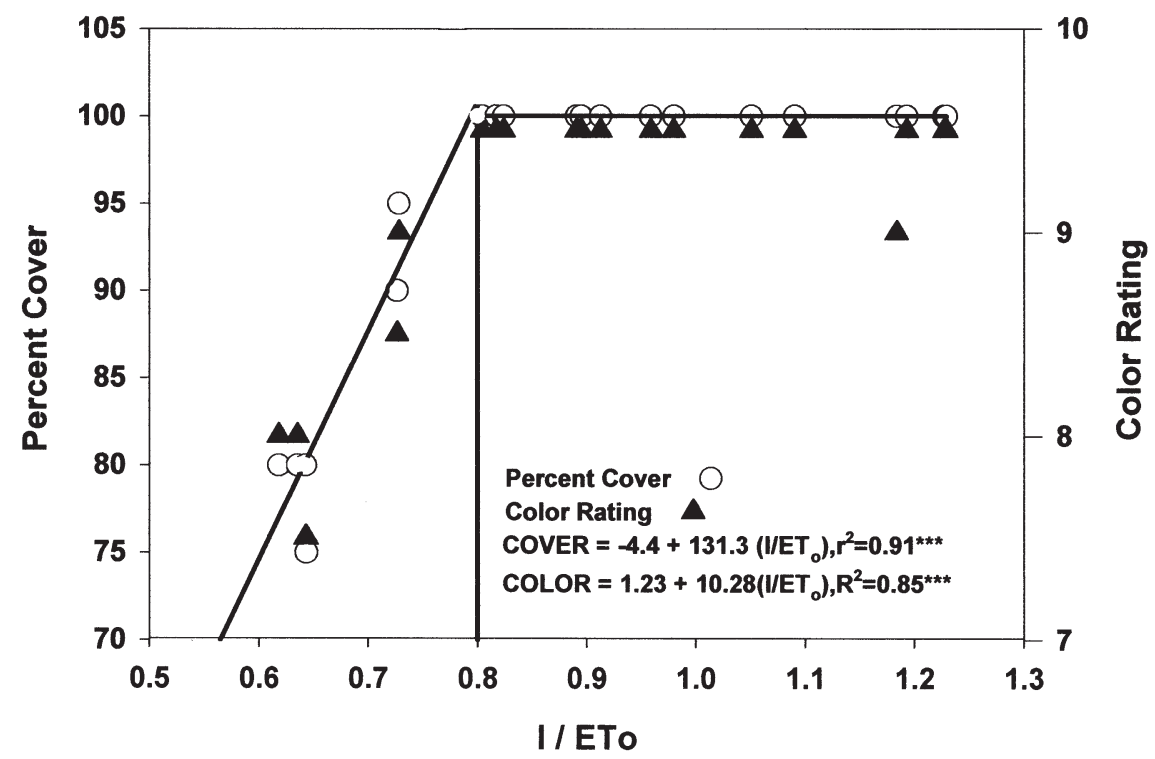

Fig. 4. Color and cover ratings vs. I/ET on Day 119 of experiment.

with the exception of color in the $0 \mathrm{~N}$ fertilization rate in the -0.40 -LF plots. The recovery period was continued until Day 189, with soil water in storage increasing with time in the minus LF treatments. The effects of $\mathrm{LF}$ and $\mathrm{N}$ fertilization rates continued to be evident during recovery, although not for all parameters. Analysis of variance indicated that $\Psi_{\mathrm{LX}}, \Psi_{\mathrm{m}}, \mathrm{ET}_{\mathrm{a}}$, I, cover and tissue moisture content did not separate significantly by LF or IF, whereas $T_{c}-T_{a}$, dry yield, color, $g_{s}$, storage/storage max $_{\text {max }}$, and drainage continued to separate during the recovery period based on the imposed water deficit period LFs (Table 3). Color separated based on IF at the end of the recovery period; however, it did not separate during the 119-d stress period. Only color and dry yield separated based on $\mathrm{N}$ fertilization at the end of the 71-d recovery period (based on the imposed treatments during the 119-d stress period).

\section{Discussion}

This study demonstrates the viability of a twice weekly, deficit irrigation strategy for tall fescue grown on a loam soil in an arid environment. Shifting from daily to twice weekly irrigations was found to have a nonsignificant effect on soil water storage depletion rates, $\Psi_{\mathrm{m}}, \Psi_{\mathrm{LX}}, \mathrm{g}_{\mathrm{s}}, \mathrm{T}_{\mathrm{c}}-\mathrm{T}_{\mathrm{a}}$, yield, color, and cover ratings. Based on this experiment, such a strategy during the peak demand months of
May $\left(15^{\text {th }}\right)$ to October $\left(15^{\text {th }}\right)$ would lead to $\approx 100$ irrigation days saved. Shifting irrigation days to different geographical areas in a community would allow water managers greater flexibility in avoiding peak system demand problems. Water restriction programs throughout the United States have imposed/enforced such landscape watering practices to reduce peak demands (Brown 1998) but typically without concern for turf quality.

Reducing the LFs in this experiment was shown to significantly affect all soil and plant parameters monitored. Reducing the LFs and thus I/ET ratios in combination with the twiceweekly irrigation strategy, could lead to water savings of $20 \%$ to $47 \%$. However, a loss in color and cover was observed when I/ET values dropped below 0.80 (threshold). A similar I/ET threshold was reported by Dean et al. (1996) for tall fescue grown in southern Nevada. Research conducted on tall fescue in Colorado by Fry and Butler (1989) found that color and cover ratings could be maintained while saving water at $75 \%$ or $100 \% \mathrm{ET}_{\mathrm{o}}$, but loss in ratings occurred when irrigations were set at $50 \%$ of ET . Ervin and Koski (1998), also in Colorado, concluded that water could be conserved on tall fescue while maintaining acceptable turfgrass quality, if irrigations occurred every $3 \mathrm{~d}$ using a crop coefficient of 0.70 .

The IF findings in this study support the selection of the lower IF which differs from local water district recommendations that

Table 3. Significant effects of LF, IF, and $\mathrm{N}$ on various soil and plant parameters based on multivariate analysis of variance (Day 189-end of recovery period).

\begin{tabular}{|c|c|c|c|c|c|c|c|c|c|c|c|c|c|}
\hline Factor & df & $\mathrm{g}_{\mathrm{s}}$ & $\Psi_{\mathrm{LX}}$ & $\Psi_{\mathrm{M}}$ & $\begin{array}{c}\text { Storage/ } \\
\text { Storage }^{\text {Max }}\end{array}$ & $\mathrm{ET}_{\mathrm{a}}$ & I & Drainage & Color & Cover & $\begin{array}{l}\text { Tissue } \\
\text { moisture }\end{array}$ & $\mathrm{T}_{\mathrm{c}}-\mathrm{T}_{\mathrm{a}}$ & $\begin{array}{c}\text { Dry } \\
\text { yield }^{z}\end{array}$ \\
\hline$\overline{\mathrm{LF}}$ & 4 & $*$ & NS & NS & $* * *$ & NS & NS & $*$ & **** & NS & NS & $* * *$ & $* * *$ \\
\hline IF & 1 & NS & NS & NS & NS & NS & NS & NS & $*$ & NS & $* * *$ & $*$ & $* * *$ \\
\hline $\mathrm{N}$ & 2 & $\mathrm{z}$ & $\mathrm{z}$ & $\mathrm{z}$ & $\mathrm{z}$ & $\mathrm{z}$ & $\mathrm{z}$ & $\mathrm{z}$ & $* * *$ & NS & NS & NS & $* * *$ \\
\hline $\mathrm{LF} \times \mathrm{IF}$ & 4 & NS & NS & NS & NS & NS & $*$ & NS & NS & NS & NS & NS & NS \\
\hline $\mathrm{LF} \times \mathrm{N}$ & 8 & $\mathrm{z}$ & $\mathrm{z}$ & $\mathrm{z}$ & $\mathrm{z}$ & $\mathrm{z}$ & $\mathrm{z}$ & $\mathrm{z}$ & *** & NS & NS & NS & NS \\
\hline $\mathrm{IF} \times \mathrm{N}$ & 2 & $\mathrm{z}$ & $\mathrm{z}$ & $\mathrm{z}$ & $\mathrm{z}$ & $\mathrm{z}$ & $\mathrm{z}$ & $\mathrm{z}$ & NS & NS & NS & NS & NS \\
\hline $\mathrm{LF} \times \mathrm{IF} \times \mathrm{N}$ & 8 & $\mathrm{z}$ & $\mathrm{z}$ & $\mathrm{z}$ & $\mathrm{z}$ & $\mathrm{z}$ & $\mathrm{z}$ & $\mathrm{z}$ & $\mathrm{z}$ & NS & NS & $*$ & NS \\
\hline
\end{tabular}

${ }^{\mathrm{z}} \mathrm{N}$ level held constant on all lysimeters.

Ns, ${ }^{*}, * *, * * *$ Nonsignificant or significant at $P \leq 0.05,0.01$, or 0.001 , respectively. currently emphasize multiple daily irrigations during summertime months in an effort to minimize runoff (Southern Nevada Water Authority, 2001). Clearly irrigators will still need to schedule irrigations with enough time between multiple applications to ensure minimal runoff. Other studies have found that less frequent irrigation encourages deeper more extensive turf root systems (Qian and Fry, 1996) and condition plants to better tolerate the effects of drought (King and Bush, 1985; Marcum, 1994). At the highest LF with daily irrigations, ET and $g_{s}$ were lower than that observed in the 0.00 LF treatment, suggesting that wetter soils in the daily irrigated 0.15 LF plots may have led to poor aeration and decreased water uptake (requiring a second order polynomial fit). In the $0.00,-0.15$, and $-0.25 \mathrm{LF}$ treatments, water savings of $9 \%, 5 \%$, and $11 \%$ were obtained by shifting from daily to twice weekly irrigations. However, results from this study suggest a greater water savings can be obtained by combining the twiceweekly irrigation with the deficit irrigation strategy. The maintenance of acceptable color and cover ratings by the -0.15 and $-0.25 \mathrm{LF}$ treatments (high $\mathrm{N}$ rate - lysimeter) suggests that deficit irrigation strategies can work in the arid southwest. Water savings achieved by using the -0.15 and -0.25 twice-weekly irrigation strategy were $37.5 \mathrm{~cm}(29 \%)$ and $51.2 \mathrm{~cm}(40 \%)$ respectively, for the 119-d period. However, such a strategy will need to be implemented carefully in the arid southwest, as the Colorado River carries a significant level of dissolved salts (Devitt et al. 1992). Greater stress associated with deficit irrigations and the accumulation of salts will lead to slower growth (Dean et al. 1996) and consequently poor recovery of tall fescue from traffic and disease. However, increasing the irrigation and leaching amounts during the nonpeak demand months (November-April) could help offset some of these problems.

The $\mathrm{ET}_{\mathrm{a}}$ measurements were made in lysimeters which were only located in the middle subplots containing the highest $\mathrm{N}$ application rate. Dry yields from subplots separated significantly by LF and $\mathrm{N}$ treatment during the stress and recovery period. Bowman and Macaulay (1991) found ET to be strongly correlated with dry yield in a study of 20 tall fescue cultivars. Lower dry yields in this study at the lower $\mathrm{N}$ rates (slopes of $\approx 180$ vs. 360 at the highest $\mathrm{N}$ rate) should translate into significantly lower ET rates, suggesting that further water savings could be achieved by managing $\mathrm{N}$ as a water conservation tool. Furthermore, the tissue $\mathrm{N}$ and moisture status, as influenced by $\mathrm{N}$ application and deficit irrigation treatments greatly influenced the turfgrass color ratings. In this experiment, $96 \%$ of the variability in color could be accounted for by a multiplicative TKN $\times$ tissue moisture content variable, suggesting that landscape managers will need to achieve a balance of $\mathrm{N}$ with irrigations to provide satisfactory color and cover while conserving water.

Greater acceptability of water deficit strategies to conserve water will occur if little loss in color and cover can be assured. Clear tradeoffs 


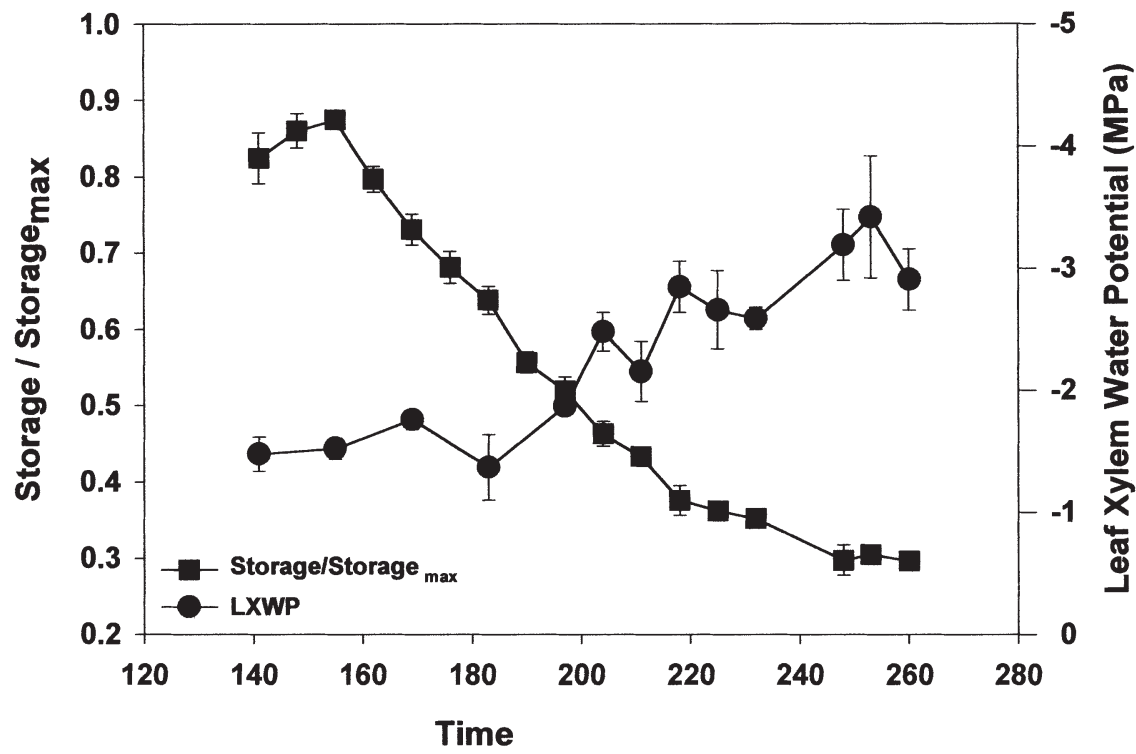

Fig. 5. Leaf xylem water potential $\left(\Psi_{\mathrm{L}}\right)$ and Storage/Storage for tall fescue grown in the $-0.40 \mathrm{LF}$ twiceweekly irrigated plots over the 119 -d water deficit period, where bars represent standard errors.

existed in this study between water savings, plant stress and turfgrass color and cover ratings. Water savings of up to $20 \%$ were achieved while maintaining color ratings well above the minimum rating of 8.0 while $\Psi_{\mathrm{LX}}$ values remained above $-1.5 \mathrm{MPa}$. However at water savings $>35 \%$, color ratings dropped below 8.0 with $\Psi_{\mathrm{LX}}$ values decreasing to values as low as -2.7 to $-4.4 \mathrm{MPa}$, which is indicative of severe stress (Johnson etal. 1993). In the higher water deficit treatments, tall fescue became more dependent on soil water in storage. In the $-0.40 \mathrm{LF}$ treatments, soil water in storage did not sustain plant needs and over the final several weeks of the stress period, turf color and cover values declined. Guz et al. (1998) found similar declines in turf quality ratings with large irrigation deficits on St. Augustinegrass (Stenotaphrum secundatum) and bermudagrass (Cynodon dactylon) in a study conducted in San Antonio, Texas. In the -0.40 LF treatment, irrigation provided an equivalent of $63 \%$ of ET. The water in storage was sufficient to supplement the deficit in irrigation water until Day 56, when Storage/Storage reached 0.52. After this level was reached, plant physiological responses such as $\Psi_{\mathrm{LX}}$ declined rapidly (Fig. 5). However, all of the treatments including the $-0.40 \mathrm{LF}$ treatment returned to $100 \%$ cover and to pre-stressed color ratings by Day 147 ( $28^{\text {th }}$ day of recovery), indicating the resiliency of tall fescue to a 119-d summer stress period. The results of this experiment indicate that implementing a twice weekly irrigation strategy at a $-0.15 \mathrm{LF}$ on tall fescue for $119 \mathrm{~d}$ during summer months in an arid environment would lead to savings of 37.5 $\mathrm{cm}$ of water and the savings of 100 irrigation days, while still maintaining acceptable color and cover ratings.

\section{Literature Cited}

Beard, J.B. 1973. Turfgrass: Science and culture. Prentice Hall, Englewood Cliffs, N.J.

Bowman, D. and L. Macaulay. 1991.Comparative evapotranspiration rates of tall fescue. Cultivars. HortScience 26(2):122-123.

Brown, C. 1998. Building an effective drought management program: Ongoing public education backed up by enforcement. Water for Texas, Texas Water Resource Inst. $10 \mathrm{p}$.

Campbell, C.A., H.R. Davidson, and F.G. Warder. 1977. Effects of fertilizer $\mathrm{N}$ and soil moisture on growth, $\mathrm{N}$ content, and moisture use by spring wheat. Canadian J. Soil Sci. 57:289-310.

Carrow, R.N. 1996. Drought avoidance characteristics of diverse tall fescue cultivars. Crop Sci.
36:371-377

Dean, D.E., D.A. Devitt, L.S. Verchick, and R.L. Morris. 1996. Turfgrass quality, growth and water-use as a function of salinity and water deficit induced stress. Agron. J. 88:844-849.

Devitt, D.A., R.L. Morris, and D.C. Bowman. 1992. Evapotranspiration, crop coefficients, and leaching fractions of irrigated desert turfgrass systems. Agron. J. 84:717-723.

Devitt, D.A., D.S. Neuman, D.C. Bowman, and R.L. Morris. 1995. Comparative water use of turfgrasses and ornamental trees in an arid environment. J. Turfgrass Mgt. 2:47-63.

Ervin, E.H. and A.J. Koski. 1998. Drought avoidance aspects and crop coefficients of Kentucky bluegrass and tall fescue under line source irrigation in the semi-arid west. Crop Sci. 38:788-795.

Fry, J. and J. Butler. 1989. Responses of tall and hard fescue to deficit irrigation. Crop Sci. 29:1536-1541.

Guz, K., J. Taylor, C. Finch, D. Emory, D. Smith, and C. Brown. 1998. San Antonio evapotranspiration pilot study report. Texas Agr. Ext. Serv., San Antonio.

Hart, W.E. and W.N. Reynolds. 1965. Analytical design of sprinkler systems. Trans. Amer. Soc. Agr. Eng. 8(1):83-89.

Johnson, R.C. 1993. Carbon isotope discrimination, water relations and photosynthesis in tall fescue. Crop Sci. 33:169-174.

Kim, K.S. and J.B. Beard. 1988. Comparative turfgrass evapotranspiration rates and associated plant morphological characteristics. Crop Sci. 28:328-331

King, M.J.and L.P. Bush. 1985. Growth and water use of tall fescue. Agron. J. 77:1-4.

Kopec, D.M., R.C. Shearman, and T.P. Riordan 1988. Evapotranspiration of tall fescue turf. HortScience 23:300-301.

Qian, Y.L. and J.D. Fry. 1996. Irrigation frequency affects zoysiagrass rooting and plant water status. HortScience 31:234-237.

Qian, Y.L., J. Fry, and W. Upham. 1997. Rooting and drought avoidance of warm-season turfgrasses and tall fescue in Kansas. Crop Sci. 37:699-704

Perstop Analytical. 1994. Total Kjeldahl nitrogen in soil and plant digest. Enviro Flow 3500 Methodology. September.

Southern Nevada Water Authority (SNWA). 2001. http://www.snwa.com/Water_Smart/Watering_Guides/watering_guides.htm

Turgeon, A.J. and F.A. Giles. 1987. Turfgrasses of Illinois. Circ. 1105, Ill. Coop.Ext. Serv., Univ. of Illinois at Urbana-Champaign.

White, R.H., M.C. Engelke, S.J. Morton, and B.A. Ruemmele. 1992. Competitive turgor maintenance in tall fescue. Crop Sci. 32:251-256. 